\title{
PEMBANGUNAN KIOS INFORMASI FASILITAS KEPEGAWAIAN BERBASIS MULTIMEDIA INTERAKTIF MENGGUNAKAN INDUSTRIAL PC
}

\author{
Erwin Yulianto ${ }^{1}$, Irwin Supriadi ${ }^{2}$ \\ ${ }^{1,2}$ Universitas Langlangbuana \\ ${ }^{1}$ rwinyulianto@yahoo.com \\ 2irwinshared@gmail.com
}

\begin{abstract}
Abstrak - Pengelolaan / Manajemen Sumber Daya Manusia (MSDM) merupakan hal mendasar yang harus diperhatikan oleh organisasi. Departemen SDM wajib mampu mengelola data karyawan dengan baik. Data karyawan tersebut akan menjadi dasar untuk menentukan kewajiban dan hak yang dapat diterima oleh karyawan yang bersangkutan, calon pegawai yang siap dipromosikan, pemenuhan diklat untuk pegawai tertentu, dan masih banyak keputusan strategis lainnya yang berhubungan dengan data kepegawaian. Hal inilah yang melahirkan Human Resources Information System (HRIS). Tujuan utama HRIS adalah memudahkan pegawai sebagai pengguna untuk menyimpan data karyawan dan mengaksesnya dengan mudah kapan pun dibutuhkan. Saat ini penerapan HRIS masih tersentralisasi di Departemen SDM sehingga informasi pegawai masih belum terinformasikan ke masing-masing pegawai. Setiap pegawai mengalami kesulitan dalam mengakses informasi pribadinya dan harus melakukan konfirmasi ke petugas departemen SDM. Berdasarkan permasalahan tersebut, kami tertarik untuk melakukan penelitian dengan menggunakan metode penelitian deskriptif untuk pengumpulan data, sementara model pembangunan sistem memakai metode Multimedia Development Life Cycle (MDLC) yang terdiri dari tahapan pengonsepan, perancangan, pengumpulan material, pengembangan dan perakitan, pengujian dan pendistribusian. Solusi yang diberikan yaitu pembangunan kios informasi berbasis multimedia interaktif menggunakan Industrial PC yang dapat diakses oleh semua pegawai sebagai pusat informasi baik informasi umum mengenai SDM maupun informasi pribadi pegawai. Hasil penelitian yang dilakukan kepada tujuh ratus pegawai dengan menggunakan metode Mean Opinion Score (MOS) yang diuji coba pada tujuh modul menghasilkan nilai rata-rata sebesar 4,18 (terdapat sedikit pemuatan namun tidak mengganggu).
\end{abstract}

Kata kunci : kios informasi, multimedia interaktif, industrial PC, fasilitas kepegawaian, mean opinion score

\begin{abstract}
Human Resources Management (HRM) is a fundamental thing that must be considered by the organization. The HR Department must be able to manage employee data properly. The employee data will be the basis for determining the obligations and rights that can be received by the employees concerned, prospective employees who are ready to be promoted, fulfillment of training for certain employees, and many other strategic decisions related to employment data. This is what gave birth to the Human Resources Information System (HRIS). The main objective of HRIS is to make it easier for employee as users to store employee data and access it easily whenever needed. Currently the implementation of HRIS is still centralized in the HR Department so that employee information is still not informed to each employee. Each employees have difficulty accessing their personal information and must confirm to the HR department officer. Based on these problems, we are interested in conducting research using descriptive research methods for data collection, while system development models are using Multimedia Development Life Cycle (MDLC) method which consists the stages of conceptualization, design, material collecting, development and assembly, testing and distribution. The solution provided is the development of interactive multimedia-based information kiosks using industrial PC that can be accessed by all employees as information center for both general information about HR and employee personal information. The results of research conducted on seven hundred employees using the Mean Opinion Score (MOS) method which were tested on seven modules produced an average value of 4.18 (there was a slight loading but not disturbing).
\end{abstract}

Keywords : information kiosk, interactive multimedia, industrial PC, employee facility, mean opinion score

\section{PENDAHULUAN}

Pengelolaan / Manajemen Sumber Daya Manusia (MSDM) merupakan hal mendasar yang harus diperhatikan oleh organisasi. Departemen SDM wajib mampu mengelola data karyawan dengan baik. Data karyawan tersebut akan menjadi dasar untuk menentukan kewajiban dan hak yang dapat diterima oleh karyawan yang bersangkutan, pegawai yang siap dipromosikan, pemenuhan diklat untuk pegawai tertentu, dan masih banyak keputusan strategis lainnya yang berhubungan dengan data kepegawaian.
Saat ini penerapan Human Resource Information System (HRIS) masih tersentralisasi di Departemen SDM sehingga informasi pegawai masih belum terinformasikan ke masing-masing pegawai, sehingga pegawai kesulitan dalam mengakses informasi pribadinya dan harus melakukan konfirmasi ke petugas departemen SDM. Kebutuhan lainnya terkait kepegawaian yaitu permasalahan dalam pengajuan cuti, lembur dan perjalanan dinas harus satu pintu melalui Departemen SDM sehingga terdapat tahapan birokrasi yang harus ditempuh. Demikian pula dari sisi penyampaian berita / 
informasi terkini terkait ketenagakerjaan / kepegawaian atau adanya ketentuan eksternal / internal yang bersifat strategis, penyampaiannya masih dilakukan melalui sosialisasi sehingga berpotensi terdapat keterlambatan penyampaian.

Kondisi yang terjadi pada saat ini dimana hampir semua aktivitas yang berhubungan dengan interaksi / komunikasi dua arah terkait penyampaian informasi selalu berhubungan dengan multimedia, baik media tulisan, media suara ataupun media gambar. Perkembangan dunia multimedia telah mengalami perkembangan yang cukup pesat yang pada akhirnya berdampak pada perkembangan desain teknologi. Salah satu bentuk multimedia penyampaian dan penyajian informasi yaitu Kios informasi yang menggabungkan komputer dan perangkat multimedia. Kios informasi dapat memberikan kemudahan bagi pegawai yang dalam hal ini sebagai pengguna untuk memperoleh informasi yang lebih komprehensif, cepat dan jelas karena penyampaian dan penyajian informasi ditampilkan secara audio visual sehingga pegawai dapat memahami informasi yang didapatkan dan/atau diinginkan (Hidayat, 2011).

Dalam rangka mendukung tahun kualitas SDM dan sistem / teknologi informasi di organisasi dan untuk lebih mengoptimalkan komunikasi antara seluruh karyawan dengan Departemen SDM, maka diperlukan fasilitas pendukung yang dapat memberikan kemudahan penyampaian informasi sehingga komunikasi \& sosialisasi mengenai kebijakan ketentuan kepegawaian terbaru dapat berjalan baik. Fasilitas pendukung dimaksud dapat diimplementasikan dalam bentuk Kios Informasi berbasis teknologi multimedia interaktif.

Keunggulan yang bisa diperoleh dengan adanya fitur multimedia interaktif pada kios informasi antara lain penyediaan berbagai navigasi bagi para penggunanya sehingga setiap pegawai dapat melakukan berbagai kegiatan dua arah seperti employee self service dalam pengajuan lembur, perjalanan dinas, cuti, melihat simulasi pensiun, pengajuan kredit, mengunduh aneka data seperti peraturan perusahaan, ketentuan internal / eksternal dan memberikan berbagai macam feedback pada pengumuman / berita terkini melalui menu yang disediakan.

\section{KAJIAN PUSTAKA DAN PERUMUSAN HIPOTESIS}

\section{A. Kios Informasi}

Salah satu pilihan bentuk media penyampaian informasi secara dua arah yaitu kios informasi yang merupakan penyatuan antara komputer (Personal Computer) dengan fungsi multimedia. Kios informasi merupakan sebuah komputer terminal yang dirancang untuk menyediakan berbagai informasi atau pelayanan secara interaktif dan biasanya berada di tempat umum. Kios informasi dapat memberikan kemudahan bagi pengguna untuk memperoleh informasi yang lebih jelas karena penyampaian informasi ditampilkan melalui multimedia (slide, gambar, suara, simulasi, grafik dan video), sehingga pengguna dapat mengerti ringkasan dari maksud informasi yang disampaikan dan/atau diinginkan. (Hidayat, 2011).

Kios informasi dibagi atas 2 jenis (Prabhat \& Kiran, 1996) :

- Dari sisi pemasaran (Point of Sales / POS), digunakan untuk membantu para officer dalam menyebarkan informasi, mengenalkan atau mempromosikan suatu produk / event / aktivitas baru sehingga menambah potensi pendapatan dan pangsa pasar penjualan.

- Dari sisi penyampaian informasi (Point of Information / POI), digunakan untuk menyampaikan informasi kepada konsumen mengenai fasilitas yang tersedia di perusahaan / produk yang ditawarkan. Penggunaan multimedia yang interaktif akan membangkitkan keingintahuan pengunjung untuk mencoba atau menjelajahi produk / sistem yang dipromosikan.

Keluaran dari penelitian ini yaitu Kios Informasi Fasilitas Kepegawaian yang merupakan anjungan informasi layar sentuh yang mampu membantu komunikasi antara Departemen SDM dengan para pegawai terkait dengan informasi kepegawaian seperti peraturan perusahaan, budaya perusahaan, statistik kepegawaian, dan berbagai ketentuan kepegawaian lainnya termasuk informasi individu pegawai.

\section{B. Multimedia Interaktif}

Hofstetter (2001) mendefinisikan multimedia sebagai pemanfaatan komputer dan/atau sistem/teknologi komunikasi untuk membuat dan menggabungkan teks, grafik, audiovisual, gambar bergerak (video dan animasi) dengan menggabungkan link, tool dan fiturfitur yang memungkinkan pengguna melakukan navigasi, berinteraksi, berkreasi, dan berkomunikasi (Suyanto, 2003).

Berdasarkan pendefinisian di atas, terdapat minimal empat komponen yang harus ada pada sebuah sistem multimedia, yaitu :

- Harus memiliki sebuah komputer / perangkat elektronik untuk mengkoordinasikan hal-hal yang dingin dilihat, didengar, dan berinteraksi dengan pengguna.

- Terdapat hubungan ke informasi secara timbal balik (dua arah).

- Terdapat alat navigasi yang memungkinkan pengguna mengakses / memberikan aksi (file transfer, respon / feedback) atas informasi tersebut. 
- Terdapat cara untuk memperoleh, memproses, dan berkomunikasi dengan informasi yang ada untuk dipergunakan sebagaimana mestinya.

Teknologi baru dalam mengembangkan multimedia merupakan penelitian yang baik sebagai prototyping. Berikut Gambar 1 adalah pengembangan Proses pengembangan sistem multimedia agar dapat menjadi prototyping yang baik dengan langkahlangkah sebagai berikut (Suyanto, 2004) :

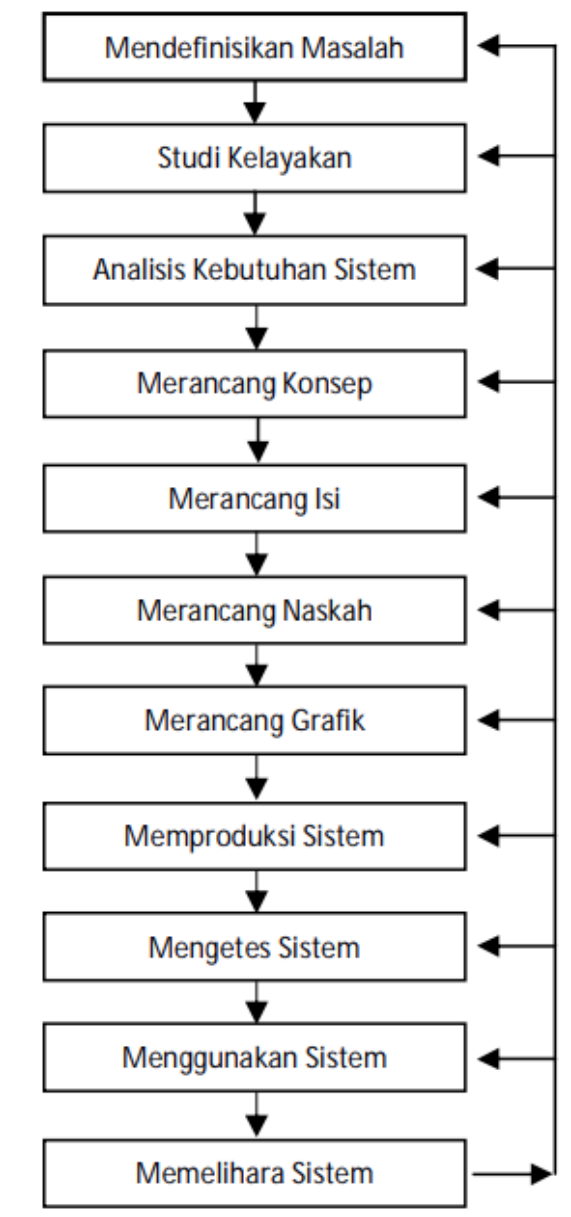

Gambar 1. Proses Pengembangan Sistem Multimedia (Suyanto, 2004)

Pada Gambar 1 dijelaskan bahwa proses pengembangan sistem / aplikasi multimedia diawali dengan mendefinisikan masalah yang terjadi pada objek penelitian, dilanjutkan dengan melakukan studi kelayakan dalam bentuk cost and benefit termasuk kemampuan organisasi dalam pembiayaan infrastruktur sistem/teknologi informasi. Langkah berikutnya yaitu melakukan analisis kebutuhan sistem yang dituangkan di dalam dokumen Business Requirement Definition (BRD) yang diserahkan kepada System Design untuk dikonversi ke dalam dokumen Software Requirement Specification (SRS) yang berisi rancangan konsep, rancangan isi, rancangan naskah dan rancangan grafik. Tim developer akan menerima dokumen SRS dimaksud untuk diproduksi, yang selanjutnya dilakukan pengujian sebelum digunakan oleh user dalam hal ini para pegawai. Fase terakhir yaitu pemeliharaan yang dilakukan secara berkala jika ditemukan adanya bugs atau adanya permintaan dari user (change for request).

Media interaktif adalah sebuah metode komunikasi / interaksi dua arah dimana keluaran (output) dari media berasal dari masukan (input) pengguna. Tidak seperti media tradisional, media interaktif dua arah dimaksudkan untuk meningkatkan pengalaman pengguna (user experience). Untuk melakukannya, media interaktif akan membutuhkan unsur-unsur seperti gambar bergerak dan grafik dinamis, Animasi, Teks Digital, Video dan Audio (Investopedia, 2019)

Berdasarkan pengertian multimedia dan interaktif tersebut, maka multimedia interaktif dapat didefinisikan sebagai suatu integrasi / penggabungan elemen beberapa media (audio, video, grafik, teks, gambar, animasi, simulasi dan lain-lain) menjadi satu kesatuan yang komprehensif, sinergis dan mutual simbiosis sehingga menghasilkan manfaat lebih bagi end user (pengguna akhir) (Reddi \& Mishra, 2003).

\section{Industrial PC}

Dengan tren baru dalam dunia sistem/teknologi informasi dan komunikasi yang muncul setiap waktu, komputer / personal computer akan menjadi lebih umum dalam semua aspek industri. Beberapa jenis lingkungan industri tertentu sulit beradaptasi dengan komputer konvensional seperti Laptop ataupun komputer desktop. Beberapa faktor lapangan yang harus mampu dipenuhi oleh komputer di area industri 4.0. sehingga tidak terjadi downtime produksi seperti debu, suhu ekstrem, guncangan, kelembaban, pembatasan / tersumbatnya aliran udara dan kurangnya waktu perawatan (maintenance).

Semua faktor lapangan tersebut sangat mempengaruhi kinerja komputer desktop atau laptop. Berbagai teknologi, konsep dan metode telah dilakukan untuk mencoba menyelesaikan banyak masalah yang ditemukan di dalam lingkungan yang ekstrem. Salah satu solusi yang tepat dalam menyelesaikan masalah tersebut adalah Industrial PC. Industrial PC merupakan perangkat elektronik untuk melakukan pengolahan data informasi yang dipakai di dunia industri sehingga terdapat perbedaan yang berbeda khususnya pada komponennya dibandingkan dengan komputer PC biasa baik dari sisi ketahanannya maupun penggunaannya yang merupakan sistem pengawasan / pengawasan operasional industri / organisasi jasa berbasis komputer yang dipakai untuk pengontrolan suatu proses bisnis. Industrial PC dapat memberikan peningkatan efektivitas, efisiensi dan produktivitas pegawai dan organisasi, serta masih banyak keuntungan lainnya yang bisa diperoleh untuk menghasilkan kinerja terbaik. 
Metode terbaik yang diusulkan yaitu menggunakan Industrial PC yang memiliki fungsi untuk meminimalisasi risiko semua komponen bergerak, seperti :

- Internal fan, pembuang energi panas dari microprocessor atau processor pada sistem komputer diganti dengan memberikan perangkat pendingin dengan tidak memakai motor penggerak

- HardDisk dengan motor sebagai penggerak piringan penyimpan yang ada di dalam harddisk disubstitusi dengan perangkat memory seperti Solid State Disk (SSD)

- Random Access Memory khusus tanpa socket dan memakai pendingin (cooler) tambahan

- Power Suply yang tidak memakai komponen cooling fan (kipas pendingin).

Solusi-solusi sebagaimana disebutkan di atas diharapkan dapat mengurangi Down Time produksi di area manufaktur / industri termasuk percepatan layanan informasi di bidang layanan jasa. Di samping itu Industrial $P C$ memberikan beberapa fitur unik yang berbeda dari PC (Personel Computer) maupun Laptop seperti compatibility, reliability, expansion port yang lebih banyak dan lain-lain.

\section{Fasilitas Kepegawaian}

Menurut Surat Edaran Menteri Tenaga Kerja nomor SE-07/MEN/1990 tentang Pengelompokan Upah, definisi fasilitas yaitu kenikmatan dalam bentuk nyata / natura yang diberikan perusahaan oleh karena hal-hal yang bersifat khusus atau untuk meningkatkan kesejahteraan pekerja, seperti fasilitas kendaraan (antar jemput pekerja atau lainnya); pemberian makan secara cuma-cuma; sarana ibadah; tempat penitipan bayi; koperasi; kantin dan lain-lain. Definisi lain dari fasilitas kepegawaian menurut Ahyari (2011) yaitu segala sesuatu di dalam organisasi yang ditempati dan dinikmati oleh para pegawai baik dalam hubungan langsung dengan pekerjaan maupun untuk mendukung kelancaran pekerjaan. Manajemen puncak harus mempertimbangkan perencanaan sarana, prasarana dan fasilitas-fasilitas kantor yang tepat, efektif dan efisien untuk para pegawai yang bekerja di perusahaannya.

Beberapa fasilitas kerja yang menjadi alat ukur kenyamanan lingkungan kerja bagi para pegawai antara lain (Ahyari, 2011) :

- Fasilitas alat kerja, merupakan tools (perkakas), alat atau barang yang berfungsi secara langsung maupun tidak langsung untuk digunakan dalam pelaksanaan pekerjaan.

- Fasilitas kelengkapan kerja, merupakan semua barang atau benda yang digunakan sebagai pendukung pekerjaan, sebagai alat bantu dan pelancar serta pelengkap dalam bekerja.

- Fasilitas sosial, merupakan fitur yang disediakan organisasi untuk kepentingan pelayanan yang prima bagi para pegawai yang berfungsi sosial dalam kegiatan seharihari.

Selain fasilitas kerja, terdapat fasilitas kepegawaian yang didapatkan dan diberikan oleh organisasi yaitu (Sinn, 2009) :

- Mendapatkan pengembangan kompetensi melalui pendidikan dan pelatihan yang merupakan penerapan ilmu untuk meningkatkan kinerja.

- Mendapatkan insentif / reward Jika seseorang melaksanakan tugasnya dengan baik. Insentif tidak harus berbentuk materi atau benda, namun bisa dalam bentuk apresiasi, pujian atau apa saja yang mampu meningkatkan semangat dan motivasi pegawai. Motivasi merupakan suatu hal yang pokok untuk mendorong seseorang dalam bekerja.

Fasilitas kepegawaian merupakan fitur yang dimiliki oleh HRIS untuk diakses oleh seluruh individu pegawai. Departemen SDM melakukan pengaturan peraturan perusahaan mengenai status kerja seperti cuti, izin, jam kerja, parameter-parameter gaji, dan sebagainya untuk selanjutnya proses administrasi akan dilakukan secara otomatis melalui HRIS. Solusi yang ditawarkan oleh HRIS yaitu informasi fasilitas kepegawaian. Berikut merupakan fasilitas kepegawaian yang biasanya diakomodir oleh HRIS :

- Time Attendance Management, data kehadiran karyawan sehari-hari merupakan hal yang penting karena mempengaruhi jumlah penghasilan yang diterima oleh pegawai yang bersangkutan. Fitur attendance mengelola data waktu datang/pulang, status kerja karyawan, jadwal shift, cuti, izin, lembur dan integrasi dengan mesin absen fingerprint (jika ada).

- Employee Self Service (ESS), adalah fitur HRIS dimana karyawan dapat mengurus administrasi kepegawaian tanpa bantuan pihak departemen SDM secara langsung seperti mencetak slip gaji, mengajukan cuti, perjalanan dinas, lembur, klaim pengobatan, dan lain-lain melalui dashboard pribadinya.

\section{E. Research Gap}

Research gap yang dapat kami rangkum berdasarkan penelitian-penelitian sebelumnya dapat dilihat pada Tabel 1. 
Tabel 1. Research Gap

\begin{tabular}{|c|l|l|l|}
\hline No & Tim Peneliti & \multicolumn{3}{|c|}{ Ringkasan Penelitian } \\
\hline 1 & $\begin{array}{l}\text { Hidayat } \\
(2011)\end{array}$ & $\begin{array}{l}\text { Integrasi Kios Informasi dengan Web Host } \\
\text { namun proses keamanan data/informasi yang } \\
\text { terdapat di server dan proses } \\
\text { transfer/pengirimannya masih minim }\end{array}$ \\
\hline 2 & $\begin{array}{l}\text { Sutomo } \\
(2017)\end{array}$ & $\begin{array}{l}\text { Dengan pembangunan Kios Informasi, } \\
\text { pengunjung lebih tertarik untuk mengunjungi } \\
\text { obyek wisata karena mudah memperoleh } \\
\text { semua informasi penting yang tersedia } \\
\text { Tampilan yang menarik dan interaktif } \\
\text { membuat pengunjung lebih memilih kios } \\
\text { informasi dibandingkan dengan cara } \\
\text { konvensional seperti brosur, dsb }\end{array}$ \\
\hline No & Tim Peneliti & \multicolumn{3}{|c}{ Ringkasan Penelitian } \\
\hline 3 & $\begin{array}{l}\text { Sukendar, } \\
\text { Wibowo, } \\
\text { Riyadi } \\
(2017)\end{array}$ & $\begin{array}{l}\text { Kios informasi yang dibuat sebagai upaya } \\
\text { peningkatan layanan wisata sejarah dan religi. } \\
\text { Penelitian ini memodelkan bangunan yang } \\
\text { terdapat pada kios informasi memakai fitur } \\
\text { virtual tour dan first person controller berbasis } \\
\text { multimedia 3D }\end{array}$ \\
\hline
\end{tabular}

Novelty yang kami kembangkan berdasarkan penelitian-penelitian terdahulu antara lain pengembangan kios informasi berbasis multimedia interaktif dua arah antara pegawai dan Departemen SDM menggunakan Industrial PC yang belum pernah diteliti sebelumnya. Kios informasi terhubung dengan server yang memiliki arsitektur 3-Tiers sehingga tingkat keandalan keamanannya tinggi.

\section{F. Hipotesis}

Berdasarkan latar belakang dan research gap di atas, maka hipotesis yang diperoleh antara lain :

- Terdapat pengaruh yang kuat antara pembangunan Kios Informasi Fasilitas Kepegawaian antara seluruh karyawan dengan departemen SDM terkait dengan kemudahan penyampaian informasi mengenai SDM dan akses informasi individual pegawai.

- Terdapat integrasi antara database kepegawaian pada HRIS dengan Kios Informasi Fasilitas Kepegawaian sehingga penyampaian update informasi selalu real time.

- Terdapat optimalisasi dan kemudahan komunikasi antara seluruh karyawan dengan Departemen SDM terkait penyampaian informasi dan sosialisasi.

\section{METODE PENELITIAN}

Penelitian ini termasuk penelitian aplikatif atau engineering (rekayasa) yaitu suatu kegiatan perancangan (design) non rutin sehingga di dalamnya terdapat kontribusi yang baru dan baik dalam bentuk produk maupun proses. Jika dilihat dari lokasi sumber datanya, penelitian ini termasuk penelitian lapangan (field research).

Model pengembangan Kios Informasi yang akan digunakan pada penelitian aplikatif ini memakai model Multimedia Development Life Cycle (MDLC) yang dikembangkan oleh Sutopo (2003). MDLC terdiri atas 6 tahapan sebagaimana Gambar 2 berikut yaitu (Binanto, 2010) :

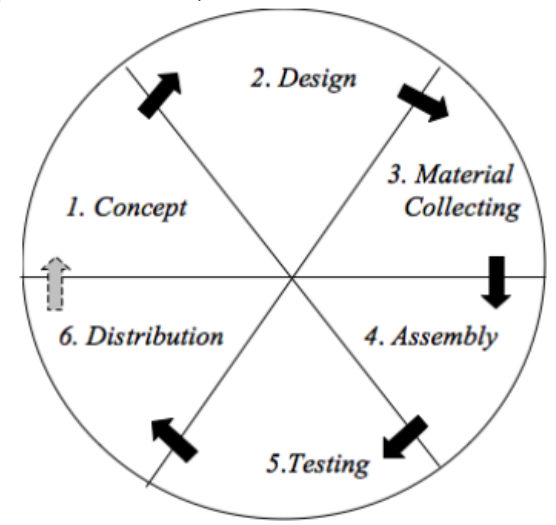

Gambar 2. Tahapan Pengembangan Sistem Multimedia

- Concept, merupakan tahapan untuk mengidentifikasi pengguna. Karakteristik pengguna perlu di analisa dan dipertimbangkan karena dapat mempengaruhi pembuatan desain.

- Design, merupakan tahapan pembuatan spesifikasi mengenai arsitektur program, tampilan, gaya, dan bahan untuk program atau kebutuhan material.

- Material Collecting, merupakan tahapan pengumpulan dan pengelompokan bahan / material yang sesuai dengan kebutuhan perancangan. Bahan-bahan / material tersebut antara lain video, gambar, clip art, foto, audio, animasi, simulasi dan lain-lain.

- Assembly, merupakan tahapan pengembangan / integrase semua obyek atau bahan multimedia. Pembuatan aplikasi didasarkan pada tahap design, yang meliputi storyboard, bagan alur dan struktur navigasi.

- Testing, dilakukan setelah menyelesaikan tahap pembuatan (assembly) dengan menjalankan aplikasi untuk dilakukan pengujian dan pengecekan kesalahan.

- Distribution, pada tahapan ini, aplikasi dan bahan-bahan/material yang telah dibangun akan disimpan dalam suatu media penyimpanan (storage). Tahapan ini juga dapat disebut sebagai tahapan evaluasi untuk pengembangan produk yang sudah jadi menjadi produk yang lebih unggul.

\section{ANALISIS DAN PERANCANGAN}

A. Analisis Kebutuhan Fungsional

Analisis kebutuhan fungsional dari Kios Informasi Fasilitas Kepegawaian dapat ditunjukkan pada Tabel 2. 
Tabel 2. Daftar Analisis Kebutuhan Fungsional

\begin{tabular}{|c|c|}
\hline Menu & Akses *) \\
\hline \multicolumn{2}{|c|}{ Modul Front End } \\
\hline Berita Terkini & $\mathrm{R}$ \\
\hline \multicolumn{2}{|c|}{ Modul Back End (Pegawai) } \\
\hline Berita Terkini & $\mathrm{R}$, Send to Email \\
\hline Peraturan Perusahaan & R, Send to Email \\
\hline Budaya Perusahaan & R, Send to Email \\
\hline Ketentuan Kepegawaian & R, Send to Email \\
\hline Fasilitas Kepegawaian & $\mathrm{R}$, Send to Email \\
\hline \multicolumn{2}{|c|}{ Modul Back End (Pegawai) } \\
\hline Statistik Kepegawaian & $\mathrm{R}$ \\
\hline Profil & RU \\
\hline \multicolumn{2}{|c|}{ Modul Administrator } \\
\hline Berita Terkini & CRUD, Upload \\
\hline Peraturan Perusahaan & CRUD, Upload \\
\hline Budaya Perusahaan & CRUD, Upload \\
\hline Ketentuan Kepegawaian & CRUD, Upload \\
\hline Fasilitas Kepegawaian & CRUD \\
\hline Statistik Kepegawaian & CRUD \\
\hline Export Database & $\mathrm{CU}$ \\
\hline Manajemen User & CRUD \\
\hline Manajemen Jabatan & CRUD \\
\hline Manajemen Pangkat & CRUD \\
\hline Manajemen Unit Kerja & CRUD \\
\hline
\end{tabular}

${ }^{*} \mathrm{C}:$ Insert/Create, $R:$ Read/View, $U:$ Edit/Update, $D$ : Delete

Dengan catatan bahwa penambahan modul bersifat dinamis, customize dan parameterized sesuai dengan kebutuhan. Sayangnya informasi-informasi pada Kios Informasi masih belum real time karena proses updating dilakukan setiap hari untuk informasi D-1.

\section{A. Sitemap Kios Informasi}

Berdasarkan Use Case Diagram di atas, berikut Gambar 3 dari sitemap dari Kios Informasi Fasilitas Kepegawaian yang akan dibangun.

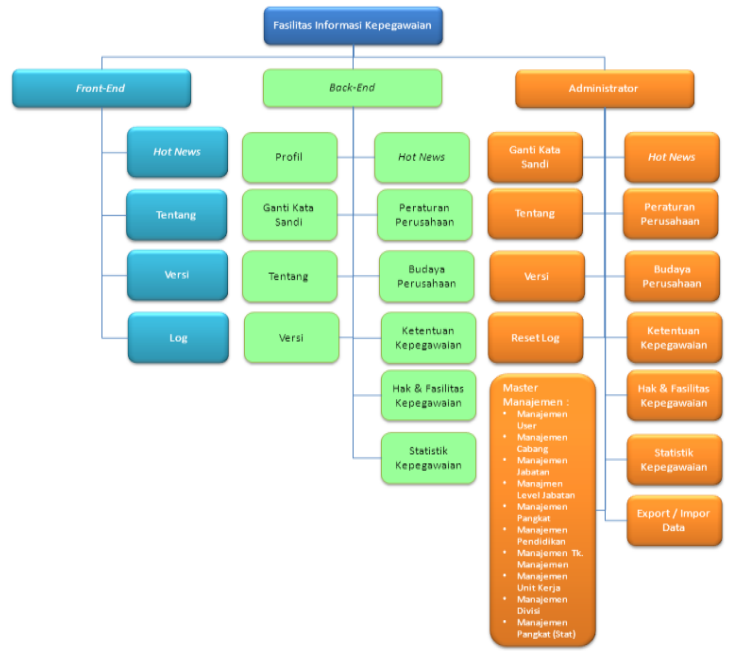

Gambar 3. Sitemap Kios Informasi Fasilitas Kepegawaian

Sitemap Kios Informasi Fasilitas Kepegawaian di atas, terbagi ke dalam tiga modul utama, antara lain :

- Modul Front-End, merupakan modul yang dikhususkan untuk menampilkan informasi seputar SDM yang dapat disebarkan sebagai konsumsi untuk karyawan maupun umum.
- Modul Back-End, merupakan modul yang hanya bisa diakses oleh karyawan. Di dalam modul Back-End terdapat sub-sub modul yang berisi informasi dan fasilitas kepegawaian yang lebih detail.

- Modul Administrator, merupakan modul yang hanya dapat diakses oleh Departemen SDM untuk melakukan pengelolaan database kepegawaian, modul dan sub modul, serta manajemen master data.

\section{B. Perancangan Basis Data}

Berikut Tabel 3 merupakan perancangan basis data yang akan digunakan sebagai landasan pembangunan Kios Informasi Fasilitas Kepegawaian.

Tabel 3. Perancangan Basis Data

\begin{tabular}{|c|c|c|}
\hline No & Nama Tabel & Fields \\
\hline 1 & TBudayaPerusahaan & $\begin{array}{l}\text { id_budaya_perusahaan (PK), } \\
\text { nama_budaya, gambar_url, judul, } \\
\text { deskripsi, id_modul (FK) }\end{array}$ \\
\hline 2 & TFasilitasKepegawaian & $\begin{array}{l}\text { id_fasilitas_kepegawaian (PK), } \\
\text { nama_fasilitas, gambar, id_modul } \\
\text { (FK), deskripsi_lengkap }\end{array}$ \\
\hline 3 & TKetentuanKepegawaian & $\begin{array}{l}\text { id_ketentuan (PK), id_modul } \\
\text { (FK), nama_ketentuan, file_url, } \\
\text { dekripsi_ketentuan }\end{array}$ \\
\hline 4 & TPeraturanPerusahaan & $\begin{array}{l}\text { id_peraturan (PK), id_modul } \\
\text { (FK), nama_peraturan, file_url, } \\
\text { dekripsi_peraturan }\end{array}$ \\
\hline 5 & TBerita & $\begin{array}{l}\text { id_berita (PK), id_modul (FK), } \\
\text { nama_berita, file_url, } \\
\text { dekripsi berita, gambar_url }\end{array}$ \\
\hline 6 & TStatistikCabang & $\begin{array}{l}\text { id_statistik (PK), id_cabang (FK), } \\
\text { bulan, nilai }\end{array}$ \\
\hline 7 & TStatistikJabatan & $\begin{array}{l}\text { id_statistik (PK), id_jabatan (FK), } \\
\text { bulan, nilai }\end{array}$ \\
\hline 8 & TStatistikPendidikan & $\begin{array}{l}\text { id_statistik (PK), id_pendidikan } \\
(\mathrm{FK}) \text {, bulan, nilai }\end{array}$ \\
\hline 9 & TStatistikPangkat & $\begin{array}{l}\text { id_statistik (PK), id_pangkat } \\
\text { (FK), bulan, nilai }\end{array}$ \\
\hline 10 & TStatistikUnitKerja & $\begin{array}{l}\text { id_statistik (PK), id_unitkerja } \\
(\mathrm{FK}) \text {, bulan, nilai }\end{array}$ \\
\hline 11 & TPegawai & $\begin{array}{l}\text { nip_user(PK), nama_lengkap, jk, } \\
\text { tgl_lahir, tgl_capeg, tgl_angkat, } \\
\text { id_cabang (FK), id_unitkerja } \\
\text { (FK), id_pangkat (FK), id_jabatan } \\
\text { (FK), status, kata_sandi, foto_url }\end{array}$ \\
\hline 12 & TUnitKerja & id_unitkerja (PK), nama_unikerja \\
\hline 13 & TJabatan & id_jabatan (PK), nama_jabatan \\
\hline 14 & TCabang & id_cabang (PK), nama_cabang \\
\hline 15 & TPendidikan & $\begin{array}{l}\text { id_pendidikan }(\mathrm{PK}) \text {, } \\
\text { nama_pendidikan }\end{array}$ \\
\hline 16 & TPangkat & id_pangkat (PK), nama_pangkat \\
\hline 17 & TModul & $\begin{array}{l}\text { id_modul (PK), nama_modul, } \\
\text { deskripsi_modul, gambar_icon, } \\
\text { parent_modul }\end{array}$ \\
\hline
\end{tabular}

Berdasarkan perancangan basis data di atas, relasi antar tabel atau dikenal dengan Entity Relationship Diagram (ERD) yang terbentuk dapat dilihat pada Gambar 4 


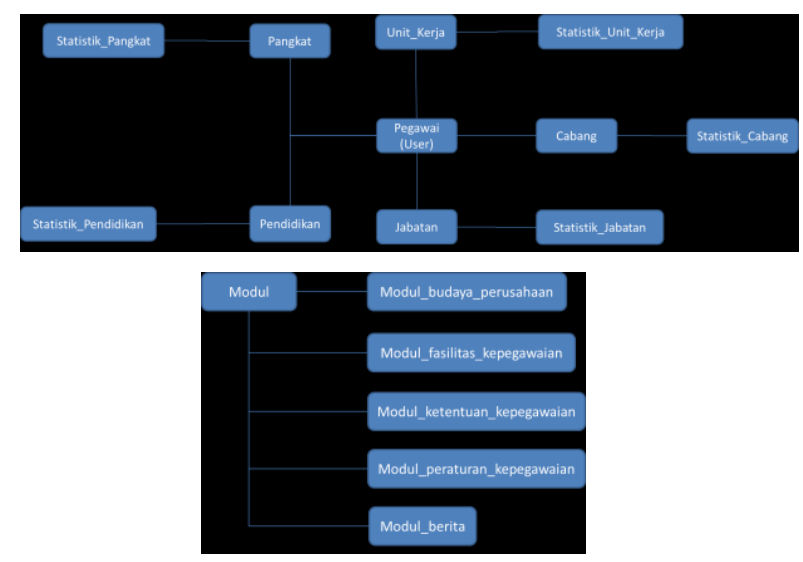

Gambar 4. Relasi Antar Tabel Dari Kios Informasi Fasilitas Kepegawaian

\section{Perancangan Antar Muka}

Berdasarkan analisis kebutuhan fungsional, sitemap kios informasi, dan perancangan basis data di atas, berikut perancangan antar muka atas Kios Informasi Fasilitas Kepegawaian yang akan dibangun :

- Menu Utama

Perancangan antar muka dari Menu Utama dapat dilihat pada Gambar 5 sebagai berikut.

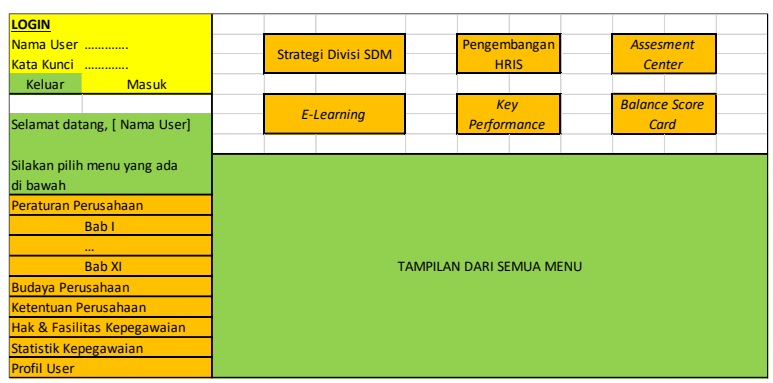

Gambar 5. Menu Berita Terkini

- $\quad$ Modul Front End

- Menu Berita Terkini

Menu ini diperuntukkan untuk seluruh karyawan terkait informasi yang bersifat global dan tidak rahasia. Menu ini memakai efek slide untuk menggeser gambar ke kiri atau ke kanan dan auto slide setiap 3 detik. Tampilan menu Berita Terkini dapat dilihat pada Gambar 6 berikut.

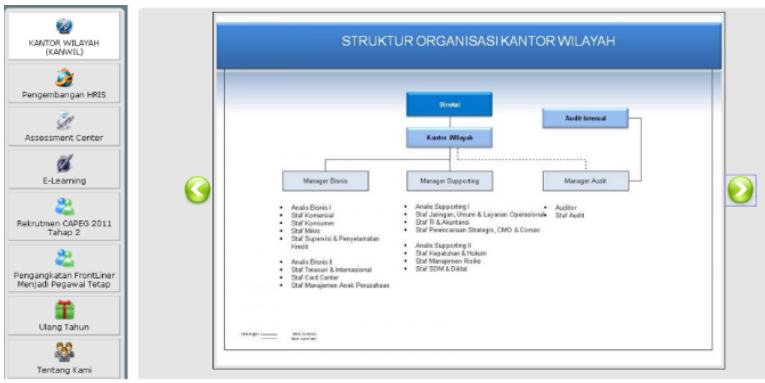

Gambar 6. Menu Berita Terkini
- Menu Tentang Kami

Menu Tentang Kami diisi dengan informasi-informasi singkat tentang definisi aplikasi, tujuan pembuatan aplikasi, fitur-fitur program, dan struktur aplikasi

- Menu Sejarah Versi

Menu Sejarah Versi berisi ringkasan mengenai perjalanan pembuatan Kios Informasi Fasilitas Informasi Kepegawaian

- Menu Log

Menu Log berisi informasi singkat mengenai jumlah pengunjung yang datang untuk melihat informasi terbaru dari Departemen SDM dan jumlah pengunjung yang melakukan aktivitas Login ke dalam aplikasi.

- Modul Back End

- Menu Dashboard

Menu Dashboard berisi daftar menu / sub modul yang bisa diakses oleh setiap pegawai. Tampilan menu Dashboard dapat dilihat pada Gambar 7 berikut.

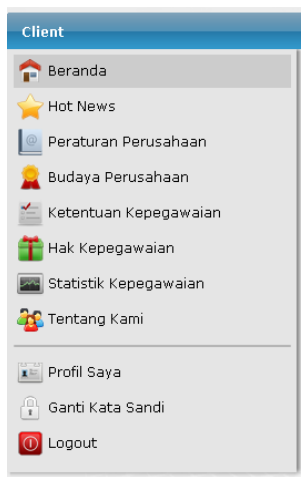

Gambar 7. Menu Dashboard

- Menu Berita Terkini

Menu Berita Terkini yang terdapat pada modul back-end secara tampilan sama persis dengan front-end namun setiap gambarnya memiliki deskripsi / keterangan yang lebih detil. Efek slide tetap digunakan termasuk auto slide setiap 3 detik. Informasi pada Berita Terkini dapat berubah secara dinamis sesuai kebutuhan. Tampilan menu Berita Terkini dapat dilihat pada Gambar 8 berikut.

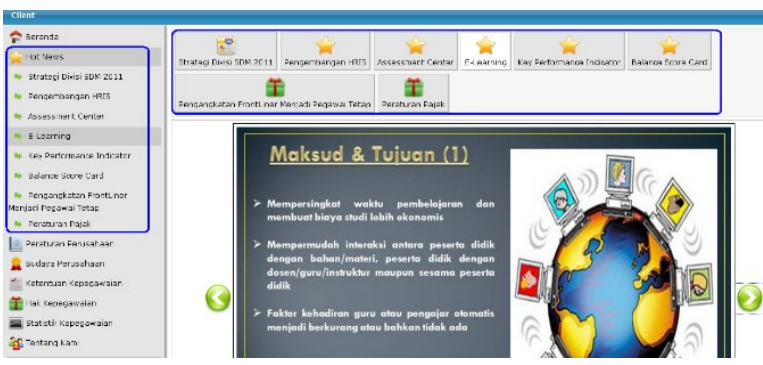

Gambar 8. Menu Berita Terkini 
- Menu Peraturan Perusahaan

Menu peraturan perusahaan berisi rincian peraturan yang berlaku di perusahaan. Peraturan perusahaan terpecah menjadi beberapa bab dimana di setiap bab tersebut bisa dimasukkan gambar apabila diperlukan. Tampilan menu Peraturan Perusahaan dapat dilihat pada Gambar 9 berikut.

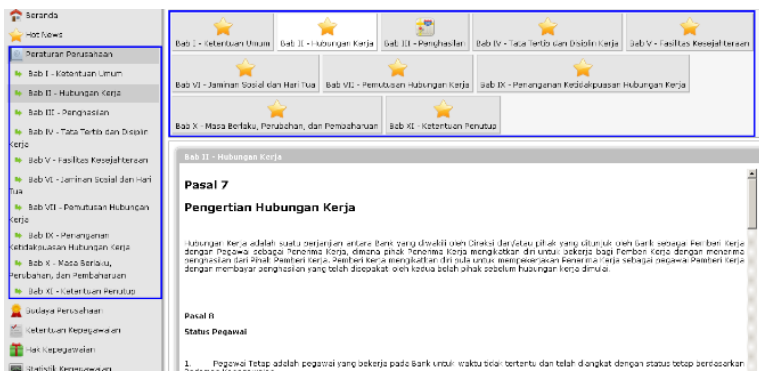

Gambar 9. Menu Peraturan Perusahaan

- Menu Budaya Perusahaan

Menu budaya perusahaan berisi butirbutir perilaku yang terangkum di dalam perusahaan.

- Menu Ketentuan Perusahaan

Menu ketentuan kepegawaian terdiri dari beberapa kategori antara lain Surat Ketentuan Direksi, Undang-Undang, Keputusan Menteri dan Peraturan Pemerintah. Setiap kategori dapat diupload gambar ataupun file *.pdf untuk mempermudah pencarian ketentuan kepegawaian. Tampilan menu Ketentuan Perusahaan dapat dilihat pada Gambar 10 berikut.

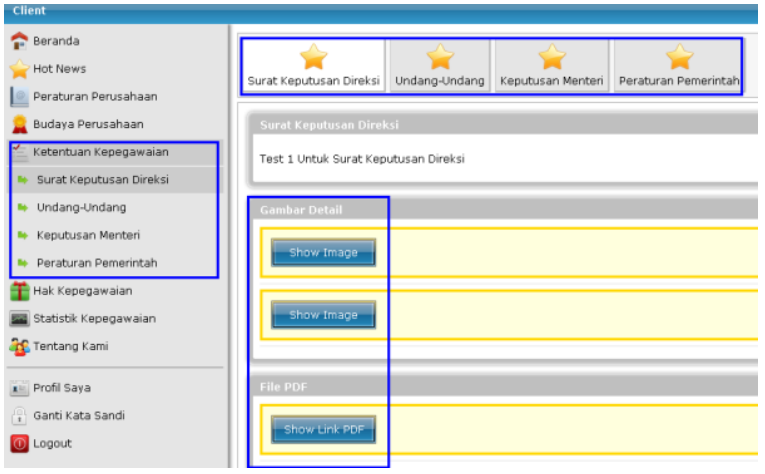

Gambar 10. Menu Ketentuan Perusahaan

- Menu Fasilitas Kepegawaian

Menu fasilitas kepegawaian berisi aneka fasilitas yang bisa diterima oleh pegawai seperti tunjangan uang makan, perjalanan dinas, honor lembur, penggantian uang kesehatan dan sebagainya.
- Menu Statistik Kepegawaian

Menu Statistik Kepegawaian berisi informasi jumlah tenaga kerja di perusahaan yang dapat disaring ke dalam beberapa kategori yaitu Pangkat, Jabatan, Pendidikan, Cabang dan Unit Kerja. Tampilan menu Statistik Kepegawaian dapat dilihat pada Gambar 11 berikut.
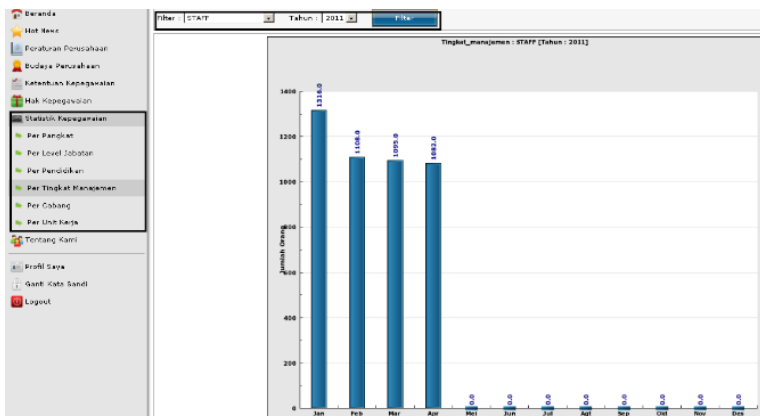

Gambar 11. Menu Statistik Kepegawaian

- Menu Profil

Menu Profil berisi informasi umum dari pegawai yang telah melakukan proses login. Informasi yang ditampilkan saat ini masih terbatas yaitu NIP, Nama, Jenis Kelamin, Tanggal Lahir, dan Foto. Tampilan menu Profil dapat dilihat pada Gambar 12 berikut.

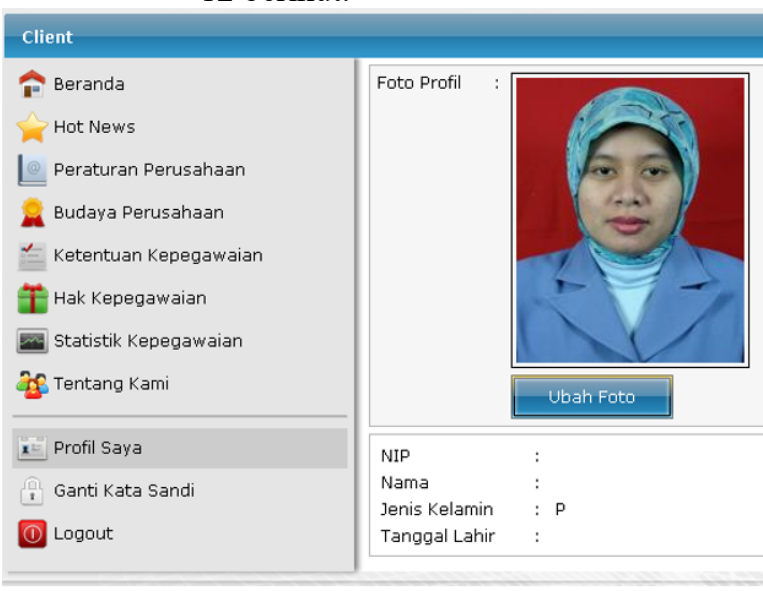

Gambar 12. Menu Profil

- Modul Administrator

Modul Administrator adalah modul utama yang dikhususkan untuk PIC (Person In Charge) pada Departemen SDM. Modul ini berfungsi sebagai sarana untuk melakukan pengelolaan database Fasilitas Informasi Kepegawaian. Administrator bisa mengakses semua menu kepegawaian termasuk master data. Adapun menu utama pada Modul Administrator dapat dilihat pada Gambar 13. 


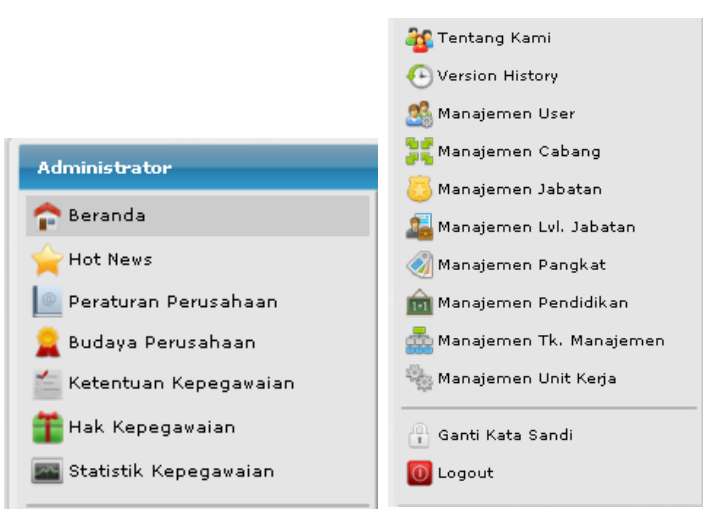

Gambar 13. Menu Utama Administrator

- Menu Berita Terkini

Pada menu Berita Terkini, admin bisa melakukan perubahan informasi yang akan ditampilkan. Terkait pengumuman / informasi setiap rencana kerja SDM beserta gambar slide-nya.

- Menu Peraturan Perusahaan

Pada menu Peraturan Perusahaan, admin bisa melakukan perubahan database dari peraturan perusahaan baik ketentuan internal maupun eksternal yang disahkan oleh Departemen Tenaga Kerja \& Transmigrasi.

- Menu Budaya Perusahaan

Pada menu Budaya Perusahaan, admin bisa melakukan perubahan database budaya perusahaan yang telah disahkan oleh Direksi sebagai pedoman pegawai dalam bersosialisasi \& berinteraksi dengan rekan kerja maupun nasabah.

- Menu Ketentuan Perusahaan

Pada menu Ketentuan Perusahaan, admin bisa melakukan perubahan database aneka ketentuan perusahaan yang terdiri dari SK Direksi, UU, Peraturan Pemerintah, dan Keputusan Menteri.

- Menu Fasilitas Kepegawaian

Pada menu Fasilitas Kepegawaian, admin bisa melakukan perubahan database fasilitas kepegawaian seperti lembur, cuti, perjalanan dinas, uang kesehatan, dan sebagainya.

Semua menu di atas dilengkapi dengan add-in image dan file PDF. Fungsional dari semua menu utama Administrator dapat dilihat pada Gambar 14.
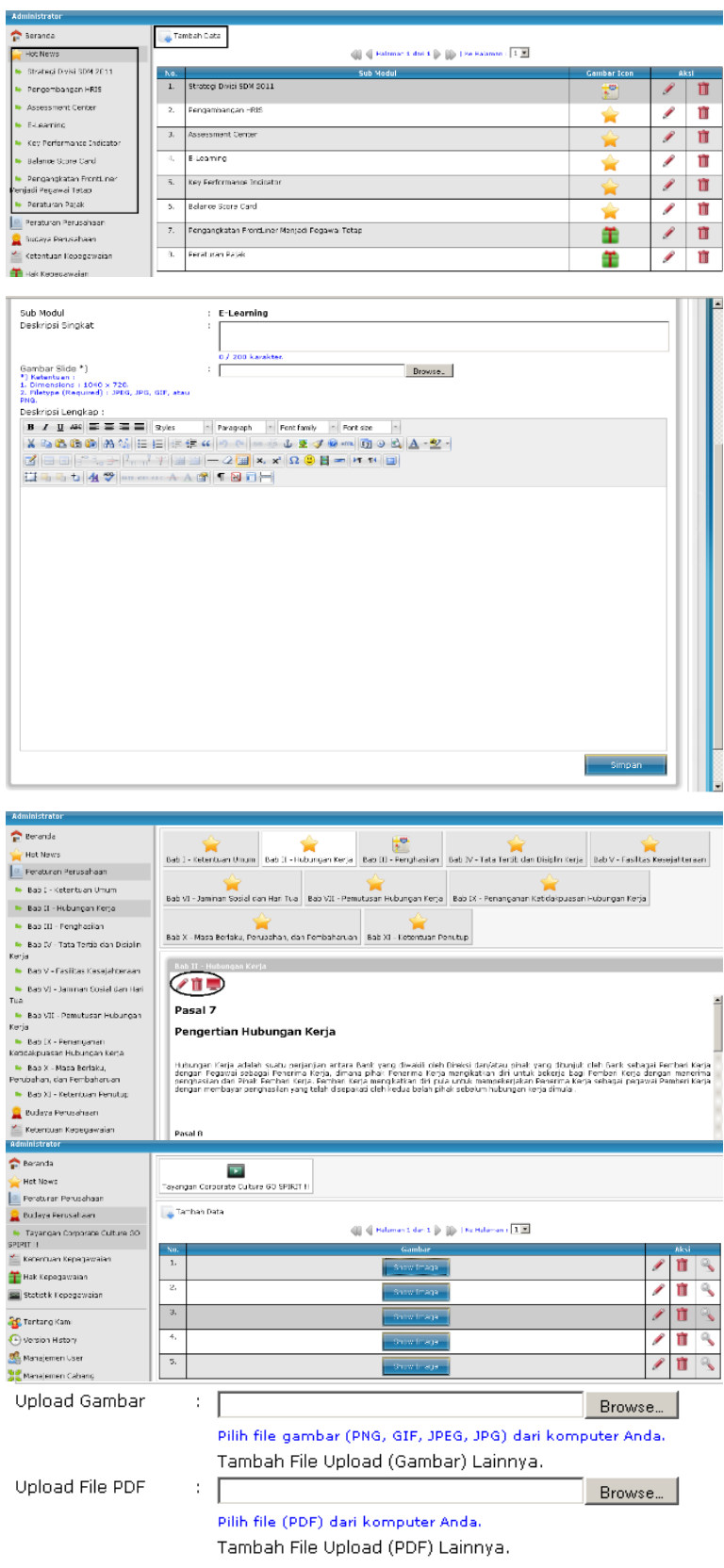

Gambar 14. Pengelolaan Menu Utama Administrator

- Menu Statistik Kepegawaian Pada menu Statistik Kepegawaian, admin bisa melakukan peng-input-an statistik kepegawaian dengan filter pangkat, level jabatan, pendidikan, tingkat manajemen, cabang, dan unit kerja. Tampilan menu Statistik Kepegawaian dapat dilihat pada Gambar 15.

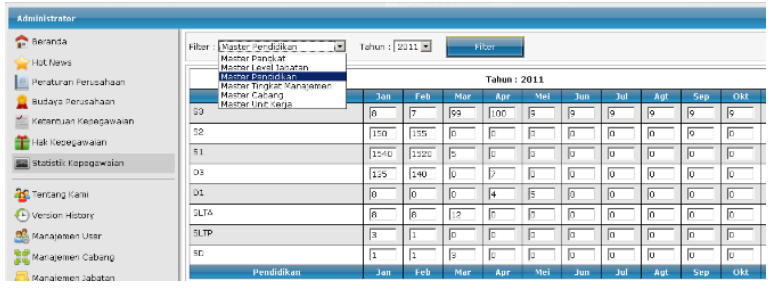

Gambar 15. Menu Statistik Kepegawaian 
- Menu Manajemen User

Pada menu Manajemen User, admin bisa melakukan proses peng-update-an master data user, seperti NIP, foto, jenis kelamin, cabang, unit kerja, dan sebagainya. Tampilan menu Manajemen User dapat dilihat pada Gambar 16 berikut.

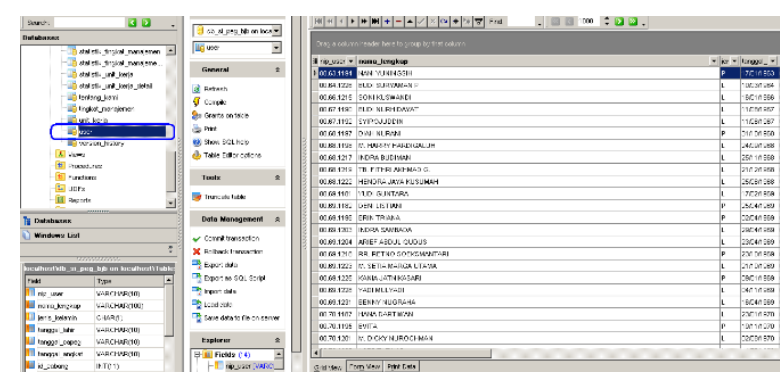

Gambar 16. Menu Manajemen User

- Menu Manajemen Master Data Pada menu Manajemen Master Data, admin bisa melakukan proses pengelolaan master data cabang, jabatan, pangkat, pendidikan dan unit kerja. Tampilan menu Manajemen Master Data dapat dilihat pada Gambar 17 berikut.

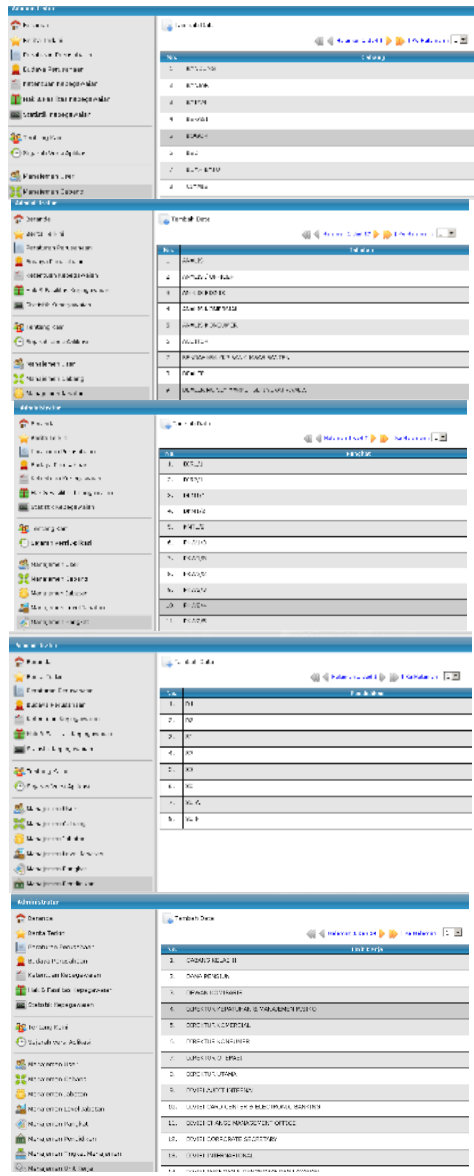

Gambar 17. Menu Manajemen Master Data

\section{Perancangan Perangkat Keras}

Perancangan hardware dan network dari Kios Informasi Fasilitas Kepegawaian dapat dilihat pada Gambar 18 berikut.

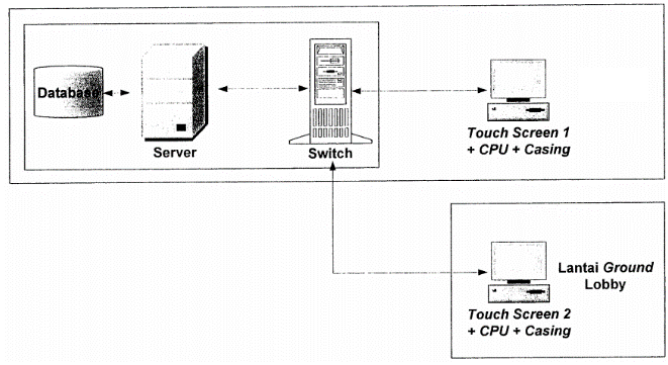

Gambar 18. Perancangan Hardware dan Network

Usulan desain Kios Informasi yang akan digunakan pada penelitian ini dapat dilihat pada Gambar 19 berikut.

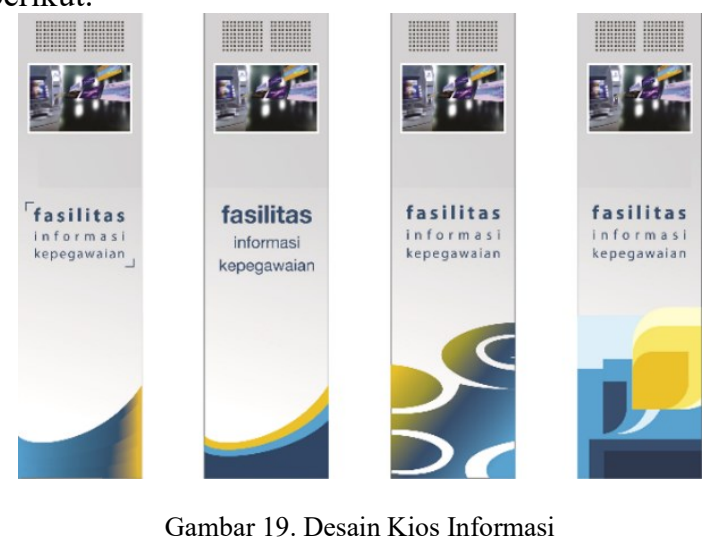

Adapun spesifikasi dari Kios Informasi Fasilitas Kepegawaian berbasis multimedia interaktif yang akan menjadi infrastruktur pendukung, memiliki spesifikasi sebagai berikut :

- Layar Sentuh LCD 12,1" dengan rasio 6:9 dengan luminance $450 \mathrm{~cd} / \mathrm{m}^{2}$, contrast ratio 700 dan resolusi SVGA $1.366 \times 768$.

- $4 U$ rackmount chassis supports up to 4 addon cards.

- $\quad$ Shock-resistant disk drive bay design holds up to two 3,5" disk drives.

- Front accessible USB \& PS/2 interfaces for easy data transfer.

- Dual front-accessible filtered cooling fans provide optimized and streamlined airflow.

- Front LEDs indicate power status, and HDD activity.

- Lockable front door prevents unauthorized access.

- $\quad$ Supports single PS/2 and redundant ATX power supplies.

\section{E. Implementasi Kios Informasi}

Implementasi dari Kios Informasi Fasilitas Kepegawaian berbasis multimedia interaktif menggunakan Industrial PC dilakukan melalui dua tahapan : 
- $\quad$ Proses import database

Seperti yang sudah dijelaskan bahwa Kios Informasi Fasilitas Kepegawaian belum memiliki informasi secara realtime. Oleh karena itu, mekanisme import database kepegawaian tetap harus dilakukan. Berikut source code untuk melakukan proses penarikan data dari HRIS :

function Insert Query (\$nama table, \$nama_field, \$vālues)

\{

mysql_query("Insert Into ".

\$nama table." (" . \$nama field

. ") ". "Values (" . \$values.

\}

$$
\text { ") ;") ; }
$$

function Update Query (\$nama table,

\$set, \$kondisi)

\{

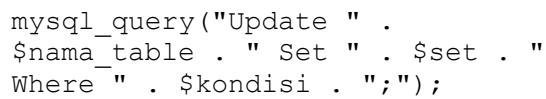

- Penempatan Kios Informasi Fasilitas Kepegawaian

Berikut Gambar 20 yang menunjukkan pembangunan Kios Informasi Fasilitas Kepegawaian telah diimplementasikan.

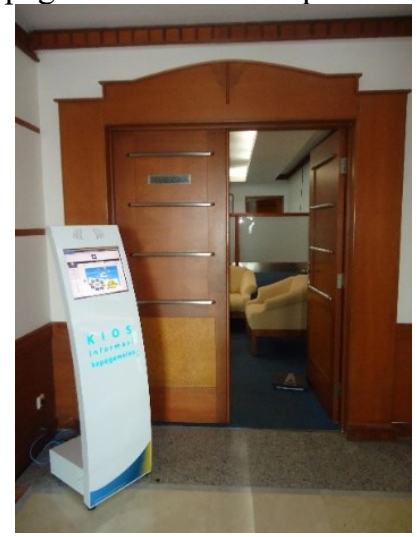

Gambar 20. Implementasi Kios Informasi Fasilitas Kepegawaian

\section{F. Hasil Pengujian Kios Informasi}

Mean Opinion Score (MOS) merupakan rekomendasi yang digunakan untuk mengukur kinerja dari suatu multimedia melalui jaringan berdasarkan pandangan dari sisi end user. Di dalam jaringan multimedia seperti audio, video, atau voice telephony terutama ketika codec digunakan untuk mengompresi bandwidth yang dibutuhkan untuk komunikasi tersebut, maka dibutuhkan MOS untuk mengukur sejauh mana kualitas dari komunikasi tersebut berdasarkan perspektif end user. End user akan memberikan penilaian dengan range angka $1-5$ yang dapat dilihat pada Tabel 4.
Tabel 4. Daftar Peringkat MOS

\begin{tabular}{|c|c|l|l|}
\hline No & $\begin{array}{c}\text { MOS } \\
\text { Level }\end{array}$ & Quality & \multicolumn{1}{|c|}{ Imparirment } \\
\hline 1 & 1 & Bad & Very Annoying \\
\hline 2 & 2 & Poor & Annoying \\
\hline 3 & 3 & Fair & Slightly Annoying \\
\hline 4 & 4 & Good & Perceptible but not Annoying \\
\hline 5 & 5 & Excellence & Imperceptible \\
\hline
\end{tabular}

Hasil pengujian dilakukan kepada tujuh ratus responden pegawai terhadap beberapa menu utama yang disediakan oleh Kios Informasi berbasis multimedia interaktif, antara lain :

- Menu Informasi SDM, berisi pengumuman atas kegiatan yang telah dilakukan maupun kegiatan yang akan dilakukan termasuk galeri dari masing-masing kegiatan / event. Pada menu ini, pengguna bisa memberikan komentar / saran sebagai bentuk feedback kepada organisasi, khususnya Departemen SDM. Pengujian yang dilakukan terdiri dari fungsi touch screen pada Kios Informasi, loading galeri kegiatan / event dan feedback dari pegawai / responden. Rata-rata nilai MOS yang diperoleh dari pengujian menu ini sebesar 4,62 dari 5,00 yang berarti hasilnya berada pada range Good to Excellence.

- Menu Budaya Perusahaan, berisi nilai-nilai perusahaan (corporate values) yang harus dipedomani oleh semua pegawai. Pengujian yang dilakukan terdiri dari fungsi touch screen pada Kios Informasi, loading pemutaran video budaya perusahaan dan proses unduh / transfer video budaya perusahaan ke Personal File Server / E-Mail pegawai. Rata-rata nilai MOS yang diperoleh dari pengujian menu ini sebesar 4,12 dari 5,00 yang berarti hasilnya berada pada range Good.

- Menu Peraturan Perusahaan, berisi peraturan dan ketentuan eksternal dari regulator / pemerintah dan internal perusahaan yang bisa dibaca dan diunduh oleh setiap pegawai. Pengujian yang dilakukan terdiri dari fungsi touch screen pada Kios Informasi, loading materi peraturan perusahaan (format *.pdf dan *.jpg) dan proses unduh / transfer file peraturan perusahaan ke E-Mail pegawai. Rata-rata nilai MOS yang diperoleh dari pengujian menu ini sebesar 4,59 dari 5,00 yang berarti hasilnya berada pada range Good to Excellence.

- Menu Statistik Kepegawaian, berisi grafik tren pertumbuhan pegawai dan informasi pegawai secara umum. Pengujian yang dilakukan terdiri dari fungsi touch screen pada Kios Informasi, fungsi filter pencarian pegawai dan generate grafik tren pertumbuhan pegawai berdasarkan kriteria yang diinginkan. Rata-rata nilai MOS yang 
diperoleh dari pengujian menu ini sebesar 3,99 dari 5,00 yang berarti hasilnya berada pada range Good.

- Menu Hak \& Fasilitas Kepegawaian, berisi daftar fasilitas kepegawaian yang diberikan oleh organisasi secara umum disertai dengan simulasi perhitungan yang informatif. Pengujian yang dilakukan terdiri dari fungsi touch screen pada Kios Informasi, loading daftar hak dan fasilitas kepegawaian secara umum dan simulasi perhitungan hak pensiun. Rata-rata nilai MOS yang diperoleh dari pengujian menu ini sebesar 4,08 dari 5,00 yang berarti hasilnya berada pada range Good.

- Menu Pribadi \& Kepegawaian, berisi informasi pribadi pegawai seperti identitas, data keluarga, data pendidikan sampai dengan data perusahaan seperti data riwayat karir, riwayat kenaikan pangkat, dan sebagainya. Pengujian yang dilakukan terdiri dari fungsi touch screen pada Kios Informasi, loading Curriculum Vitae, update data pribadi dan/atau perusahaan serta proses unduh / transfer file peraturan perusahaan ke E-Mail pegawai. Rata-rata nilai MOS yang diperoleh dari pengujian menu ini sebesar 4,01 dari 5,00 yang berarti hasilnya berada pada range Good.

- Menu Employee Self Service, berisi fungsi utama dari Kios Informasi untuk melakukan business action seperti pengajuan cuti, lembur dan perjalanan dinas. Pengujian yang dilakukan terdiri dari fungsi touch screen pada Kios Informasi, pengajuan cuti, lembur dan perjalanan dinas yang akan dievaluasi dan di-approve oleh Departemen SDM. Rata-rata nilai MOS yang diperoleh dari pengujian menu ini sebesar 3,87 dari 5,00 yang berarti hasilnya berada pada range Fair to Good.

\section{KESIMPULAN DAN SARAN}

\section{A. Kesimpulan}

Berdasarkan hasil pembahasan penelitian, pengujian hipotesis dan implikasi hasil, kesimpulan yang dapat diambil dari penelitian ini antara lain :

- Kios Informasi Fasilitas Kepegawaian dapat mengoptimalkan penyampaian informasi kepada seluruh karyawan serta akses informasi individual pegawai dengan menggunakan teknologi layar sentuh (touch screen), file transfer dan feedback. Hal ini diperkuat dengan rata-rata nilai MOS yang diperoleh dari pengujian menu Informasi SDM dengan peringkat MOS 4,62 (Good to Excellence), Budaya Perusahaan dengan peringkat MOS 4,12 (Good) dan Peraturan Perusahaan dengan peringkat MOS 4,59 (Good to Excellence).
- Integrasi antara database kepegawaian pada HRIS dengan Kios Informasi Fasilitas Kepegawaian masih terdapat kelemahan yaitu masih dilakukannya proses import database sehingga update informasi kepegawaian masih belum real time (D-1). Hal ini diperkuat dengan rata-rata nilai MOS yang diperoleh dari pengujian menu Employee Self Service yang hanya memperoleh peringkat MOS di 3,87 atau Fair to Good.

- Komunikasi antara seluruh karyawan dengan Departemen SDM terkait penyampaian informasi dan sosialisasi menjadi lebih mudah dan terjadi mekanisme dua arah sehingga pengaruhnya lebih optimal. Selain itu, fungsi komunikasi diperkuat dengan adanya proses update data, pembuatan simulasi dan generate grafik. Hal ini diperkuat dengan rata-rata nilai MOS yang diperoleh dari pengujian menu Statistik Kepegawaian dengan peringkat MOS 3,99 (Good), Hak \& Fasilitas Kepegawaian dengan peringkat MOS 4,08 (Good) dan menu Pribadi \& Kepegawaian dengan peringkat MOS 4,01 (Good).

\section{B. Saran}

Penelitian yang dilakukan saat ini masih memiliki keterbatasan sehingga masih memungkinkan untuk dikembangkan. Rekomendasi penelitian untuk pengembangan di masa mendatang yaitu :

- Pengembangan HRIS bisa dikembangkan lebih lanjut melalui konektivitas intranet/internet sehingga pengelolaan data pegawai bisa dua arah baik oleh Departemen SDM maupun oleh inidividu pegawai.

- Pembangunan HRIS dapat dilakukan dengan memakai aneka media seperti PC (menggunakan browser), smartphone (berbasis android), dan media cloud.

- Penambahan fungsional aplikasi seperti dashboard executive summary, manajemen absensi dan employee self service.

\section{DAFTAR PUSTAKA}

Sumber dari Buku, Jurnal \& Karya Ilmiah :

Ahyari, Agus, (2011), Manajemen Produksi Perencanaan Sistem Produksi, Yogyakarta, BPFE

Binanto, Iwan, (2010), Multimedia Digital Dasar Teori dan Pengembangannya, Yogyakarta, Andi

Hidayat, Tonny, (2011), Pengintegrasian Sistem Kios Informasi Dengan Web Host Menggunakan Adobe Director, Jurnal Dasi, Vol. 12, No. 1, pp 46-55 
Prabhat, Andleigh, K \& Kiran, Thakrar, (1996). Multimedia System Design, New Jersey, Prentice Hall Inc.

Reddi, Usha V. \& Mishra, Sanjaya, (2003), Educational Multimedia- A Handbook for Teacher-Developers, New Delhi, The Commonwealth of Learning Commonwealth Educational, Media Centre for Asia

Sinn, Ahmad Ibrahim Abu, (2009), Manajemen Syariah, Jakarta, PT. Raja Grafindo Persada

Suhendar, Akip; Wibowo, Hermansyah Andi; Riyadi, Akhmad, (2017), Aplikasi Virtual Tour Sebagai Kios informasi Berbasis First Person Control pada kawasan Wisata Banten Lama, Jurnal Litbangda, Vol. 9, No. 1, pp78-84

Surat Edaran Menteri Tenaga Kerja nomor SE-07/MEN/1990 tentang Pengelompokan Upah

Sutomo, Rudi, (2017), Analisa dan Perancangan Kios Informasi Taman Buah Mekarsari Berbasis Multimedia, Jurnal Multinetics, Vol. 2, No. 1, pp 1519

Sutopo, Ariesto Hadi, (2003), Multimedia Interaktif dengan Flash, Yogyakarta, PT. Graha Ilmu

Suyanto, M, (2004), Analisis Dan Desain Aplikasi Multimedia Untuk Pemasaran, Yogyakarta, Andi Offset

Sumber dari Internet :

Investopedia, (2019), Interactive Media, https://www.investopedia.com/terms/i/in teractive-media.asp, diakses tanggal 22 Mei 2019

Archivioguerrapolitica, (2019), Penjelasan Tenatang Multimedia Serta Kelebihan Dan Kekuranganya, http://www.archivio guerrapolitica.org/2018/02/21/penjelasan -tenatang-multimedia-serta-kelebihandan-kekuranganya/, diakses tanggal 19 Oktober 2019 